\title{
Metal Complex Derivatives of Azole: a Study on Their Synthesis, Characterization, and Antibacterial and Antifungal Activities
}

\author{
Keshia F. Castillo, ${ }^{a, \#}$ Nestor J. Bello-Vieda, ${ }^{b, \#}$ Nelson G. Nuñez-Dallos, ${ }^{b}$ Homero F. \\ Pastrana, ${ }^{c}$ Adriana M. Celis, ${ }^{a}$ Silvia Restrepo, ${ }^{a}$ John J. Hurtado ${ }^{* b}$ and Alba G. Ávila ${ }^{c}$

\begin{abstract}
${ }^{a}$ Departamento de Ciencias Biológicas, Laboratorio de Micología y Fitopatología, ${ }^{b}$ Departamento de Química, Grupo de Investigación en Química Inorgánica, Catálisis y Bioinorgánica and 'Departamento de Ingeniería Eléctrica y Electrónica, Centro de Microelectrónica, Universidad de Los Andes, Bogotá D.C., Colombia
\end{abstract}

\begin{abstract}
Four new zinc complex derivatives of azoles and ligands were synthesized and isolated as white air-stable solids and characterized by elemental analyses, thermogravimetric analysis (TGA), infrared spectroscopy, nuclear magnetic resonance (NMR) and mass spectra. The elemental analysis, theoretical calculations and NMR show that the complexes likely have a 1:1 (M:L) stoichiometry and tetrahedral geometry. To evaluate the biological activity of the complexes and to discuss the role of metal ions and structural properties, the ligands and their metal complexes have been studied. Their antimicrobial activity was determined in vitro by agar-well diffusion and broth microdilution against nine bacterial strains and seven fungal strains with clinical relevance. In vitro assays showed that the complexes exhibited moderate antibacterial and/or antifungal activities. The antimicrobial activity was found to be more active for the metal complexes than the ligands. The metal complexes that contained copper and cobalt, respectively, displayed notable antibacterial and antifungal effects against all the tested bacterial strains. The minimum inhibitory concentration $50\left(\mathrm{MIC}_{50}\right)$ values were in the range $2454-0.7 \mu \mathrm{g} \mathrm{mL}^{-1}$. Metal complexes were more effective at inhibiting bacteria than fungi. The results could provide a high-potential solution for antimicrobial growth resistance, for both bacteria and fungi.
\end{abstract}

Keywords: zinc, copper, cobalt, azole ligands, antibacterial activity, antifungal activity

\section{Introduction}

Microorganisms, such as bacteria, molds and yeasts that are associated with the surrounding environment, may be related to the development of severe infections in humans. ${ }^{1}$ Bacteria such as Staphylococcus aureus, Escherichia coli and Pseudomonas aeruginosa are the most common pathogens associated with hospital and community-acquired infections, and they are responsible for diseases such as urinary tract infections, pneumonia and bloodstream infections. ${ }^{2}$ Fungal infections are also responsible for high rates of mortality and morbidity, primarily in immunosuppressed patients. ${ }^{3}$ Besides providing resistance against some fungal and bacterial strains, a limited number of compounds are available for the treatment of fungal and bacterial infections. ${ }^{4}$ In this context, azole derivatives have displayed antifungal and antibacterial activity. This activity is related to their ability to bind readily to enzymes and receptors in biological systems;

*e-mail: jj.hurtado@uniandes.edu.co

\#These authors contributed equally to this work in fungi, azoles bind to the heme cofactor that is located in the active site of cytochrome P450 14 $\alpha$-demethylase, and they inhibit the conversion pathway from lanosterol to ergosterol, an essential step in the synthesis of the fungal cell membrane. In bacteria, azoles act as an inhibitor of enoyl acyl carrier protein reductase (FabI), a protein that is involved in fatty acids synthesis. ${ }^{5-15}$ When azole ligands are coordinated to $\mathrm{Co}^{2+}, \mathrm{Cu}^{2+}$ and $\mathrm{Zn}^{2+}$, they have higher antimicrobial activity than the free ligand, and in some cases, they exceed that of standard test substances. ${ }^{16-20}$ The increased antimicrobial activity is likely related to azole's better solubility, bioavailability and interaction with DNA (deoxyribonucleic acid) through intermolecular associations. ${ }^{19,20}$ Increased lipophilicity in the complexes reduces the permeability barrier of cells and slows normal cellular processes in microorganisms, resulting in increased antimicrobial activity. ${ }^{19-23}$ With the aim of developing new antifungal and antibacterial compounds, we report the synthesis, characterization, and antibacterial and antifungal activities of metal complex derivatives of azoles. Four new zinc complexes were tested along with another two 
additional and previously reported complexes that contain copper and cobalt. Their structural properties in terms of donor groups, size, and metallic ions along with their antibacterial and antifungal activities are discussed, together with the interpretation of possible mechanisms that might be responsible for inhibition. A detailed characterization of each complex is provided.

\section{Experimental}

\section{Synthesis and characterization of ligands and complexes}

All manipulations were routinely performed in an inert atmosphere (nitrogen) using standard Schlenk-tube techniques. All reagent-grade solvents were dried, distilled, and stored under a nitrogen atmosphere. The starting compounds $1 H$-benzotriazole, 2,6-bis(bromomethyl) pyridine, $\mathrm{ZnCl}_{2}, \mathrm{CoCl}_{2} \cdot 6 \mathrm{H}_{2} \mathrm{O}, \mathrm{CuCl}_{2} \cdot 2 \mathrm{H}_{2} \mathrm{O}, 1 \mathrm{H}$-indazole, 3,5-dimethylpyrazole (1), $1 H$-1,2,4-triazole and 1,3-bis(bromomethyl)benzene were used as received from Aldrich. Elemental analyses $(\mathrm{C}, \mathrm{H}$ and $\mathrm{N})$ were made with a Thermo Scientific ${ }^{\mathrm{TM}}$ FLASH 2000 CHNS/O Analyzer. Fourier transform infrared (FTIR) spectra were recorded on a Thermo Nicolet NEXUS FTIR spectrophotometer using $\mathrm{KBr}$ pellets. Nuclear magnetic resonance (NMR) spectra were recorded on a Bruker Ascend ${ }^{\mathrm{TM}}-400$ spectrometer. Chemical shifts are reported in ppm relative to a $\mathrm{SiMe}_{4}$ $\left({ }^{1} \mathrm{H}\right)$ internal standard. The mass spectra of the ligands were obtained on a Micromass Quattro Q-TOF LC/MS. The mass spectra of the complex were obtained on a Thermo Scientific LCQ Fleet electrospray ionization ESI-ion trap mass spectrometer. Melting points were determined on a Mel-Temp® $1101 \mathrm{D}$ apparatus in open capillary tubes, and they are uncorrected. Thermogravimetric analyses (TGA) of the complexes were obtained on a NETZSCH STA 409 PC/PG by collecting 8-10 mg of the complexes in nitrogen media. The samples were subjected to dynamic heating over a temperature range of $30-700{ }^{\circ} \mathrm{C}$ with a heating rate of $10{ }^{\circ} \mathrm{C} \mathrm{min}{ }^{-1}$. The $\mathrm{TG}$ curves were analyzed to give the percentage mass loss as a function of the temperature. The molecular modeling calculations were performed by semi-empirical methods (PM6) with MOPAC2012 software, version $15.152 \mathrm{~W}^{24,25}$ and Gabedit, version 2.3.8. ${ }^{26}$ The geometry was optimized under a vacuum (gas phase) with this method, with an RMS gradient of $0.01 \mathrm{kcal} \mathrm{mol}^{-1} \AA^{-1}$. The vibrational frequencies were also obtained from the optimized geometries. The minimum inhibitory concentration $50\left(\mathrm{MIC}_{50}\right)$ was measured on Microtiter plate spectrophotometer (Microplate reader, Biorad-680, BioTek Instruments). The synthetic protocols for the previously reported ligands bis $(3,5-$ dimethyl-1-pyrazolyl)methane (2), bis(1,2,4-triazol-1-yl) methane (3), 3,5-bis(3,5-dimethylpyrazol-1-ylmethyl) toluene (4), 2,6-bis(benzotriazol-1-ylmethyl)pyridine (5) and 3,5-bis(benzotriazol-1-ylmethyl)toluene (6) and complexes dichloro[bis(3,5-dimethylpyrazole- $N N$ )]zinc(II) (8), dichloro[bis(3,5-dimethyl-1-pyrazolyl)methane- $N N$ ] zinc(II) (9), dichloro[bis(1,2,4-triazol-1-yl)methane- $N N$ ] zinc(II) (10), dichloro[bis(3,5-dimethyl-1-pyrazolyl) methane-NN]copper(II) (15) and dichloro[bis(3,5dimethyl-1-pyrazolyl)methane-NN]cobalt(II) (16) are shown in the Supplementary Information section.

\section{Synthesis of ligands}

\section{Synthesis of 1,3-bis(indazol-1-ylmethyl)benzene (7)}

In a Schlenk tube equipped with a reflux condenser, 1,3-bis(bromomethyl)benzene (1.20 mmol; $317.9 \mathrm{mg}$ ), $1 \mathrm{H}$-indazole (2.61 mmol; $308.5 \mathrm{mg}$ ) and toluene $(15 \mathrm{~mL})$ were added and the mixture was heated and refluxed for $72 \mathrm{~h}$. The solvent was evaporated, water was added to the solid residue, and then it was neutralized with a $10 \%$ sodium bicarbonate solution. The aqueous mixture was extracted with 3-10 mL volumes of dichloromethane. The organic layer was dried with magnesium sulfate, and the solution was concentrated and cooled at $-5^{\circ} \mathrm{C}$ for $24 \mathrm{~h}$. The pure compound was obtained by crystallization from dichloromethane-pentane and washed with $n$-pentane and n-hexane. Yield $324.1 \mathrm{mg}$ (79\%); mp: $175-176^{\circ} \mathrm{C}$; IR (KBr) $\mathrm{v} / \mathrm{cm}^{-1} 3117,1625,1511,1468,1386,1320,1135,1007$, 789, 757; ${ }^{1} \mathrm{H}$ NMR (400.1 MHz, DMSO- $\left.d_{6}\right) \delta 8.45(\mathrm{~s}, 2 \mathrm{H}$, 12,12'), 7.63 (dd, 4H, J 49.9, 8.5 Hz, 7,7',10,10'), 7.38 (s, 1H, 4), 7.35-7.26 (m, 1H, 1), 7.25-7.18 (m, 4H, 8, ', 9,9'), 7.06-6.99 (m, 2H, 2,2'), 5.61 (s, 4H, 5,5'); ${ }^{13} \mathrm{C} \mathrm{NMR}$ (101 MHz, DMSO- $d_{6}$ ) $\delta 148.28$ (C6,C6'), 137.32 (C3'), 129.37 (C1), 128.0 (C4), 127.96 (C8,C8'), 125.9 (C9,C9'), 124.5 (C12,C12'), 121.54 (C3,C3'), 121.52 (C2,C2'), 121.08 (C7,C7'), 117.5 (C10,C10'), 56.09 (C5,C5'); anal. calcd. for $\mathrm{C}_{22} \mathrm{H}_{18} \mathrm{~N}_{4}$ : C 78.08, H 5.36, N 16.56; found: C 78.05, H 5.10, N 16.55\%; HRMS (FTMS + pESI) $\mathrm{m} / \mathrm{z}$, calcd. for $[\mathrm{M}+\mathrm{H}]^{+}:$339.1604; found: 339.1632 . The atom numbering for compound (7) is shown at Scheme 1.

\section{Synthesis of complexes}

Synthesis of dichloro[3,5-bis(3,5-dimethylpyrazol-1ylmethyl)toluene-NN]zinc(II) (11)

A solution of 3,5-bis(3,5-dimethylpyrazol-1-ylmethyl) toluene (4) $(1.07 \mathrm{mmol} ; 330.8 \mathrm{mg})$ in $5 \mathrm{~mL}$ of acetone was added to a solution of zinc(II) chloride $(1.10 \mathrm{mmol}$; $151.9 \mathrm{mg}$ ) in $5 \mathrm{~mL}$ of acetone. The reaction mixture was stirred at room temperature (rt) for $5 \mathrm{~h}$. The resulting white 


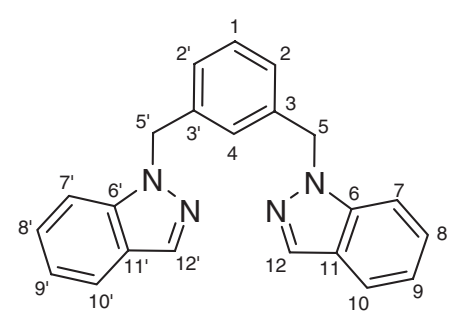

Scheme 1. The atom numbering for compound (7).

solid was filtered off and washed with acetone and ethanol. Yield: $208.5 \mathrm{mg}$ (44\%); mp: $190-191{ }^{\circ} \mathrm{C}$; IR (KBr) $\mathrm{v} / \mathrm{cm}^{-1}$ 1712, 1607, 1556, 1469, 1422, 1364, 1221, 1047, 787, $419 ;{ }^{1} \mathrm{H}$ NMR (400.1 MHz, DMSO- $\left.d_{6}\right) \delta 6.80$ (s, 2H), 6.55 (s, 1H), $5.82(\mathrm{~s}, 2 \mathrm{H}), 5.10(\mathrm{~d}, 4 \mathrm{H}, J 7.5 \mathrm{~Hz}), 2.22(\mathrm{~s}, 3 \mathrm{H})$, 2.13-2.04 (m, $12 \mathrm{H})$; anal. calcd. for $\mathrm{C}_{19} \mathrm{H}_{24} \mathrm{Cl}_{2} \mathrm{~N}_{4} \mathrm{Zn}$ : C 51.32, H 5.44, N 12.60; found: C 51.32, H 5.34, N 12.52\%; MS $(\mathrm{FTMS}+\mathrm{IT}) \mathrm{m} / z$, calcd. for $[\mathrm{M}+\mathrm{H}]^{+}: 445.07$; found: 445.03 .

Synthesis of dichloro[2,6-bis(benzotriazol-1-ylmethyl) pyridine-NM]zinc(II) (12)

A solution of 2,6-bis(benzotriazol-1-ylmethyl)pyridine (5) $(0.29 \mathrm{mmol} ; 100.5 \mathrm{mg})$ in $10 \mathrm{~mL}$ of ethanol was added to a solution of zinc(II) chloride $(0.31 \mathrm{mmol} ; 41.6 \mathrm{mg})$ in $10 \mathrm{~mL}$ of ethanol. The reaction mixture was stirred for $1 \mathrm{~h}$ (rt), giving a white solid, which was filtered off and washed with ethanol and dichloromethane. Yield: $114 \mathrm{mg}(81 \%)$; $\mathrm{mp}:>300^{\circ} \mathrm{C}$; IR (KBr) v / $\mathrm{cm}^{-1} 3069,2989,2929,1597$, 1578, 1459, 1428, 1230, 1150, 788, 748, 490; ${ }^{1} \mathrm{H}$ NMR $\left(400.1 \mathrm{MHz}, \mathrm{DMSO}-d_{6}\right) \delta 8.02(\mathrm{dd}, 2 \mathrm{H}, J 5.8,2.8 \mathrm{~Hz}), 7.80$ (t, $1 \mathrm{H}, J 7.8 \mathrm{~Hz}), 7.53(\mathrm{dd}, 2 \mathrm{H}, J 5.8,2.8 \mathrm{~Hz}), 7.42-7.34$ (m, 4H), 7.26 (d, 2H, J 7.8 Hz), 5.99 (s, 4H); anal. calcd. for $\mathrm{C}_{19} \mathrm{H}_{15} \mathrm{Cl}_{2} \mathrm{~N}_{7} \mathrm{Zn}$ : C 47.78, H 3.17, N 20.53; found: $\mathrm{C}$ 47.75, H 3.14, N 20.43\%; MS (FTMS + IT) $\mathrm{m} / z$, calcd. for $[\mathrm{M}+\mathrm{Na}]^{+}:$530.04; found: 530.18 .

Synthesis of dichloro[3,5-bis(benzotriazol-1-ylmethyl) toluene-NN]zinc(II) (13)

A solution of 3,5-bis(benzotriazol-1-ylmethyl)toluene (6) $(0.17 \mathrm{mmol} ; 60.5 \mathrm{mg})$ in $2 \mathrm{~mL}$ of ethanol was added to a solution of zinc(II) chloride $(0.17 \mathrm{mmol} ; 23.2 \mathrm{mg})$ in $1 \mathrm{~mL}$ of ethanol. The reaction mixture was stirred for $3 \mathrm{~h}$ (rt), giving a white solid that was filtered off and washed with ethanol and dichloromethane. Yield: $48.2 \mathrm{mg}$ (58\%); mp: $271{ }^{\circ} \mathrm{C}$; IR (KBr) v / $\mathrm{cm}^{-1} 1609,1496,1456,1318$, 1230, 1170, 1142, 781, 749, 488; ${ }^{1} \mathrm{H}$ NMR $(400.1 \mathrm{MHz}$, DMSO- $\left.d_{6}\right) \delta 8.04(\mathrm{~d}, 2 \mathrm{H}, J 8.3 \mathrm{~Hz}), 7.71(\mathrm{~d}, 2 \mathrm{H}, J 8.3 \mathrm{~Hz})$, 7.46 (dd, 2H, $J 11.2,4.0 \mathrm{~Hz}), 7.42-7.34(\mathrm{~m}, 2 \mathrm{H}), 7.16$ (s, $1 \mathrm{H}), 7.09(\mathrm{~s}, 2 \mathrm{H}), 5.90(\mathrm{~s}, 4 \mathrm{H}), 2.20(\mathrm{~s}, 3 \mathrm{H})$; anal. calcd. for $\mathrm{C}_{21} \mathrm{H}_{18} \mathrm{Cl}_{2} \mathrm{~N}_{6} \mathrm{Zn}$ : C 51.40, H 3.70, N 17.13; found: C 51.40; H 3.70; N 17.12\%; MS (FTMS + IT) $\mathrm{m} / z$, calcd. for $\left[\mathrm{M}+\mathrm{Na}+\mathrm{DMSO}^{+}\right.$: 590.02; found: 590.25 .
Synthesis of dichloro[1,3-bis(indazol-1-ylmethyl)benzene$N N$ Jinc(II) (14)

A solution of 1,3-bis(indazol-1-ylmethyl)benzene (7) $(0.181 \mathrm{mmol} ; 61.2 \mathrm{mg})$ in $5 \mathrm{~mL}$ of ethanol was added to a solution of zinc(II) chloride $(0.177 \mathrm{mmol} ; 24.2 \mathrm{mg})$ in $2 \mathrm{~mL}$ of ethanol. A white solid precipitate was produced immediately, but the reaction mixture was stirred for $30 \mathrm{~min}$ (rt). The white solid was filtered off and washed with ethanol and diethyl ether. Yield: $37.0 \mathrm{mg}(44 \%)$; mp: $>300{ }^{\circ} \mathrm{C}$; IR $(\mathrm{KBr}) \vee / \mathrm{cm}^{-1} 3100,1628,1520,1479,1438,1366$, 1315, 1172, 1035, 854, 758, 559; ${ }^{1} \mathrm{H}$ NMR (400.1 MHz, DMSO- $\left.d_{6}\right) \delta 8.46\left(\mathrm{~s}, 2 \mathrm{H}, 12,12^{\prime}\right), 7.63(\mathrm{dd}, 4 \mathrm{H}, J$ 48.6, $\left.8.5 \mathrm{~Hz}, 7,7^{\prime}, 10,10^{\prime}\right), 7.38$ (s, 1H, 4), 7.35-7.28 (m, 1H, 1), 7.26-7.17 (m, 4H, 8, ' ',9,9'), 7.06-6.99 (m, 2H, 2,2'), 5.62 (s, $4 \mathrm{H}, 5,5^{\prime}$ ); anal. calcd. for $\mathrm{C}_{22} \mathrm{H}_{18} \mathrm{Cl}_{2} \mathrm{~N}_{4} \mathrm{Zn}$ : C 55.67, H 3.82, N 11.80; found: C 55.63, H 3.80, N 11.76\%; MS (FTMS + IT) $\mathrm{m} / z$, calcd. for $[\mathrm{M}+\mathrm{Na}]^{+}: 495.01$; found: 494.75 .

In vitro antibacterial and antifungal activity

Strains and isolates

Reference strains and clinical isolates of bacteria: $S$. aureus ATCC 25923, MRSA, E. faecalis ATCC 19433, B. cereus ATCC 14579, E. coli ATCC 25922, P. aeruginosa ATCC 28593, E. aerogenes ATCC 13048, S. typhimurium ATCC 14028 and S. flexneri ATCC 29903; yeasts: Candida albicans ATCC 10231, Candida krusei ATCC 6258 and Candida parapsilosis ATCC 22019, and molds: Aspergillus flavus, Aspergillus fumigatus ATCC MYA-3626, Fusarium oxysporum (FMR 9788), and Fusarium solani (FMR 4591), were used during the in vitro susceptibility test and were obtained from the Laboratory of Mycology and Phytopathology, at Universidad de los Andes, Bogotá D.C., Colombia, with the exception of the Fusarium species, which were kindly provided by the Microbiology Unit of the Universitat Rovira i Virgili. Bacteria were subcultured on nutrient agar (NA) (Oxoid, UK), yeasts were cultured on Sabouraud dextrose agar (SDA) (Oxoid) and molds were grown on potato dextrose agar (PDA) (Oxoid) at $37{ }^{\circ} \mathrm{C}$ for yeast and bacteria, and at $25{ }^{\circ} \mathrm{C}$ for molds to assess the purity and viability of the isolates. All the strains used here were previously characterized, both genotypically and phenotypically.

Antibacterial and antifungal activities of metal salts, ligands and their metal complexes

All the metal salts, ligands and their respective metal(II) complexes were tested against the strains by agar-well diffusion method and broth microdilution method. The test procedures that were selected for the agar-well dilution method were in accordance with the M02-A, 
M44-A and M51-A methods recommended by the Clinical and Laboratory Standards Institute (CLSI). ${ }^{27-29}$ Metal complexes, free ligands and metal salts were dissolved in dimethyl sulfoxide (DMSO) to a final concentration of $100 \mathrm{mM}$.

Bacterial and fungal inoculum containing approximately


spread on the surface of Mueller-Hinton agar plates with a sterile cotton swab. Wells (5 $\mathrm{mm}$ in diameter) were cut in the media with a sterile metallic tube, and $20 \mu \mathrm{L}$ of each sample were placed in each well.

The plates were incubated at $37{ }^{\circ} \mathrm{C}$ (bacteria and yeasts) or $25^{\circ} \mathrm{C}$ (molds) for 24 to $48 \mathrm{~h}$. DMSO (1\%) was selected as the negative control to determine if it played any participating role in the biological screening. Gentamicin (24 $\left.\mu \mathrm{g} \mathrm{mL}^{-1}\right)$ and fluconazole $\left(15 \mu \mathrm{g} \mathrm{mL}^{-1}\right)$ were used as the standard reference drugs. The antibacterial and antifungal activity was determined by measuring the diameter of the inhibition zone around each well. The results were calculated as the means of three replicates.

For the broth microdilution method, the procedure was carried out in accordance with the M07-A, M27-A and M38-A methods recommended by the CLSI. ${ }^{30-32}$ Inocula containing approximately $10^{4} \mathrm{CFU}$ or conidia $\mathrm{mL}^{-1}$ were incubated with serial dilutions of the compounds in LuriaBertani broth for bacteria or RPMI 1640 medium for fungi in 96-well plates. The plates were incubated at $37^{\circ} \mathrm{C}$ for 6, 24 and $48 \mathrm{~h}$ for bacteria, yeasts and molds, respectively. After the incubation time, the absorbance at $600 \mathrm{~nm}$ for bacteria and $630 \mathrm{~nm}$ for fungi were read in a microtiter plate spectrophotometer. Gentamicin $\left(5 \mu \mathrm{g} \mathrm{mL}^{-1}\right)$ and fluconazole ( $3 \mu \mathrm{g} \mathrm{mL}^{-1}$ ) were used as the standard reference drugs.

\section{Minimum inhibitory concentration (MIC)}

Compounds exhibiting high antibacterial or antifungal activities were selected for MIC studies. The $\mathrm{MIC}_{50}$ of the selected compound was determined in two replicates by broth microdilution method according to CLSI guidelines. ${ }^{30-32}$ Serial dilutions were performed from 2454 to $0.7 \mu \mathrm{g} \mathrm{mL}^{-1}$ to determinate the concentration of the compound that inhibited $50 \%$ of the microorganism's growth.

\section{Results and Discussion}

Schemes 2-4 show the azole ligands and complexes under study.

\section{Synthesis}

The synthesis of (3) was performed according to the method described by Juliá et al. ${ }^{33}$ with some modifications. We found that the synthesis was better when the mixture reaction was initiated with the triazol salt. For this reason, a triazol sodium derivative was obtained and then added to the reaction mixture together with tetrabutylammonium bromide and $\mathrm{CH}_{2} \mathrm{Cl}_{2}$. The ligand (7) was synthesized by the reaction between $1 \mathrm{H}$-indazole and 1,3-bis(bromomethyl) benzene in toluene. The deprotonation of the $1 H$-indazole with $\mathrm{KOH}$ or $\mathrm{NaOH}$ did not produce good results because it yielded an unidentified yellow oil.

We reported the reaction of 2,6-bis(bromomethyl) pyridine with $1 H$-indazole. When the reaction was performed with $\mathrm{KOH}$, it produced a mixture of two regioisomers at a low yield (10\%), which corresponded to the N1 and N2 disubstituted indazoles. The electron pair that is located at $\mathrm{N} 2$ becomes more reactive than the corresponding one at N1. ${ }^{34,35}$ Compound (7) was isolated as a white solid with a $79 \%$ yield by crystallization from dichloromethane-pentane. The ligand was characterized by NMR using DEPT-135 for the identification of the methylene group at $56.06 \mathrm{ppm}$. The ${ }^{13} \mathrm{C}$ and ${ }^{1} \mathrm{H}$ chemical

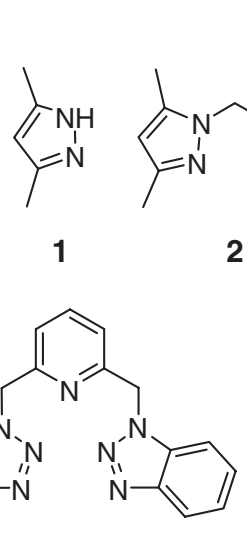

5<smiles>Cc1cc(Cn2nnc3ccccc32)cc(Cn2nnc3ccccc32)c1</smiles>

6<smiles>Cc1cc(Cn2nc(C)cc2C)cc(Cn2nc(C)cc2C)c1</smiles><smiles>c1ccc(Cn2ncc3ccccc32)cc1</smiles>

7

Scheme 2. Azole ligands. 


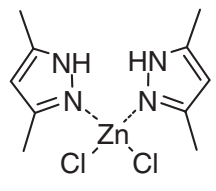

8

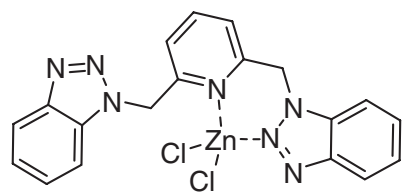

12



Scheme 4. $\mathrm{Cu}^{2+}$ and $\mathrm{Co}^{2+}$ complexes with ligand (9).

shifts were assigned with the aid of a heteronuclear single quantum coherence (HSQC) experiment. The ligands (2-7) exhibit important chelating properties, as evidenced by the immediate precipitation of the complexes when the ligand is mixed with $\mathrm{Zn}^{2+}$ salt to form complexes (9-14). All the zinc complexes are non-hygroscopic, white solids, and they are air-stable at room temperature. These complexes show very low solubility in organic solvents but they are soluble in dimethylformamide (DMF) and DMSO.

\section{Elemental analysis}

The spectroscopy, analytical data and theoretical calculations reported here are consistent with the proposed formulation. Table 1 shows the elemental analysis, melting point, and ligand and complex colors. These results allowed us to propose the 1:1 (M:L) relative rate in the complexes (9-16) and their general form, $\mathrm{M}(\mathrm{L})(\mathrm{Cl})_{2}$. Complex (8) had a 2:1 (M:L) relative rate, resulting in an $\mathrm{M}(\mathrm{L})_{2}(\mathrm{Cl})_{2}$ type.

Ligands (2-7) coordinate in a bidentate manner to the metals and (1) coordinates in a monodentate manner. The most probable geometry for complexes with these characteristics is tetrahedral geometry. ${ }^{36-38}$ Melting points above $190{ }^{\circ} \mathrm{C}$ for these complexes reveal their high stability.<smiles></smiles>

10<smiles></smiles>

11<smiles></smiles>

14
Infrared spectroscopy

A vibrational analysis in which ligands were compared with their complexes showed that the coordination of the ligand to the metal causes an absence or shift in the bands to higher wave numbers. Those results indicate the greater rigidity of the chemical bonds in the complex (Table 2).

The zone between 3200 and $2600 \mathrm{~cm}^{-1}$ in (1) (Scheme 2) shows intensive peaks from the intermolecular $\mathrm{N}-\mathrm{H}$ hydrogen bonds in the free ligand. In complex (8), this hydrogen interaction is not possible because the metal is coordinated via $\mathrm{N} 2$ from the pyrazole. The shift to a longer frequency in $\mathrm{N}-\mathrm{H}$ is conferred by the increased bond strength from the loss of the hydrogen interaction. The presence of the $\mathrm{N}-\mathrm{H}$ band indicates the coordination of the metal through the $\mathrm{N} 2$ of the azole. ${ }^{39}$ The formation of ligands (2-7) is confirmed by the complete absence of $\mathrm{N}-\mathrm{H}$ stretching in the corresponding azole. In (9) (Scheme 3), the metal-ligand interaction results in the absence of the $\mathrm{N}-\mathrm{C}$ band $\left(1353 \mathrm{~cm}^{-1}\right)$ assigned to the pyrazoles in the free ligand, indicating coordination. The aliphatic asymmetric $\mathrm{C}-\mathrm{H}$ vibration in free ligand $(3)\left(3115 \mathrm{~cm}^{-1}\right)$ appears to shift, and in complex (10), it was observed at $3120 \mathrm{~cm}^{-1} .18,40$ It was also possible to observe the shift and the decreased intensity of the band at $1494 \mathrm{~cm}^{-1}$ as assigned to the $\mathrm{N}-\mathrm{C}$ and $\mathrm{C}=\mathrm{C}$ of the pyridine ring in (5), which appear in (12) at $1500 \mathrm{~cm}^{-1} .41,42$ This shift indicates a moderate interaction between the metal center and the pyridinic nitrogen of the ligand (Scheme 2). In the case of (6) and (13), the band that assigned $\mathrm{C}=\mathrm{C}$ to the aromatic toluene ring was found in both the ligands and complexes; it indicates that there was no $\mathrm{Zn}$-toluene interaction. In addition to complexes (8-14), weak absorption bands in the $450-550 \mathrm{~cm}^{-1}$ ranges could 
Table 1. Analytical and physical data of the ligands and complexes

\begin{tabular}{|c|c|c|c|c|c|c|}
\hline \multirow{2}{*}{$\begin{array}{l}\text { Compound } \\
\text { (formula) }\end{array}$} & \multirow{2}{*}{$\begin{array}{c}\text { Molecular } \\
\text { weight } /\left(\mathrm{g} \mathrm{mol}^{-1}\right)\end{array}$} & \multirow{2}{*}{$\begin{array}{c}\text { Color } \\
\text { (yield) / \% }\end{array}$} & \multirow{2}{*}{ Melting point $/{ }^{\circ} \mathrm{C}$} & \multicolumn{3}{|c|}{ Calculated (found) $/ \%$} \\
\hline & & & & $\mathrm{C}$ & $\mathrm{H}$ & $\mathrm{N}$ \\
\hline $\begin{array}{l}2 \\
\left(\mathrm{C}_{11} \mathrm{H}_{16} \mathrm{~N}_{4}\right) \\
\end{array}$ & 204.28 & $\begin{array}{l}\text { white } \\
(60.0)\end{array}$ & 106 & $\begin{array}{c}64.68 \\
(64.64) \\
\end{array}$ & $\begin{array}{r}7.90 \\
(7.82) \\
\end{array}$ & $\begin{array}{r}27.43 \\
(27.42) \\
\end{array}$ \\
\hline $\begin{array}{l}3 \\
\left(\mathrm{C}_{5} \mathrm{H}_{6} \mathrm{~N}_{6}\right) \\
\end{array}$ & 150.15 & $\begin{array}{l}\text { white } \\
(66.0)\end{array}$ & $142-143$ & $\begin{array}{c}40.00 \\
(39.97)\end{array}$ & $\begin{array}{c}4.03 \\
(3.95) \\
\end{array}$ & $\begin{array}{r}55.97 \\
(55.92) \\
\end{array}$ \\
\hline $\begin{array}{l}4 \\
\left(\mathrm{C}_{19} \mathrm{H}_{24} \mathrm{~N}_{4}\right) \\
\end{array}$ & 308.43 & $\begin{array}{l}\text { white } \\
(67.5) \\
\end{array}$ & 92 & $\begin{array}{c}73.99 \\
(74.01) \\
\end{array}$ & $\begin{array}{r}7.84 \\
(7.82) \\
\end{array}$ & $\begin{array}{r}18.17 \\
(18.17) \\
\end{array}$ \\
\hline $\begin{array}{l}5 \\
\left(\mathrm{C}_{19} \mathrm{H}_{15} \mathrm{~N}_{7}\right) \\
\end{array}$ & 341.38 & $\begin{array}{l}\text { white } \\
(57.0)\end{array}$ & $121-123$ & $\begin{array}{c}66.85 \\
(66.88) \\
\end{array}$ & $\begin{array}{r}4.43 \\
(4.43) \\
\end{array}$ & $\begin{array}{c}28.72 \\
(28.70) \\
\end{array}$ \\
\hline $\begin{array}{l}\mathbf{6} \\
\left(\mathrm{C}_{21} \mathrm{H}_{18} \mathrm{~N}_{6}\right) \\
\end{array}$ & 354.42 & $\begin{array}{l}\text { white } \\
(42.9) \\
\end{array}$ & 147 & $\begin{array}{c}71.17 \\
(71.12) \\
\end{array}$ & $\begin{array}{c}5.12 \\
(5.10) \\
\end{array}$ & $\begin{array}{c}23.71 \\
(23.60) \\
\end{array}$ \\
\hline $\begin{array}{l}7 \\
\left(\mathrm{C}_{22} \mathrm{H}_{18} \mathrm{~N}_{4}\right) \\
\end{array}$ & 338.41 & $\begin{array}{l}\text { white } \\
(79.8)\end{array}$ & 175 & $\begin{array}{c}78.08 \\
(78.05)\end{array}$ & $\begin{array}{c}5.36 \\
(5.10) \\
\end{array}$ & $\begin{array}{r}16.56 \\
(16.55) \\
\end{array}$ \\
\hline $\begin{array}{l}8 \\
\left(\mathrm{C}_{10} \mathrm{H}_{16} \mathrm{Cl}_{2} \mathrm{~N}_{4} \mathrm{Zn}\right)\end{array}$ & 326.53 & $\begin{array}{l}\text { white } \\
(76.0)\end{array}$ & $229-232$ & $\begin{array}{c}36.56 \\
(36.50)\end{array}$ & $\begin{array}{c}4.91 \\
(4.90) \\
\end{array}$ & $\begin{array}{r}17.05 \\
(17.04) \\
\end{array}$ \\
\hline $\begin{array}{l}9 \\
\left(\mathrm{C}_{11} \mathrm{H}_{16} \mathrm{Cl}_{2} \mathrm{~N}_{4} \mathrm{Zn}\right)\end{array}$ & 340.56 & $\begin{array}{l}\text { white } \\
(75.4)\end{array}$ & $>300$ & $\begin{array}{c}38.80 \\
(38.76)\end{array}$ & $\begin{array}{c}4.74 \\
(4.72) \\
\end{array}$ & $\begin{array}{r}16.45 \\
(16.43) \\
\end{array}$ \\
\hline $\begin{array}{l}\mathbf{1 0} \\
\left(\mathrm{C}_{5} \mathrm{H}_{6} \mathrm{Cl}_{2} \mathrm{~N}_{6} \mathrm{Zn}\right)\end{array}$ & 286.43 & $\begin{array}{l}\text { white } \\
(94.5)\end{array}$ & $>300$ & $\begin{array}{c}20.97 \\
(20.92) \\
\end{array}$ & $\begin{array}{c}2.11 \\
(2.11)\end{array}$ & $\begin{array}{c}29.34 \\
(29.24) \\
\end{array}$ \\
\hline $\begin{array}{l}11 \\
\left(\mathrm{C}_{19} \mathrm{H}_{24} \mathrm{Cl}_{2} \mathrm{~N}_{4} \mathrm{Zn}\right)\end{array}$ & 444.71 & $\begin{array}{l}\text { white } \\
(43.7) \\
\end{array}$ & 190 & $\begin{array}{c}51.32 \\
(51.32) \\
\end{array}$ & $\begin{array}{r}5.44 \\
(5.34) \\
\end{array}$ & $\begin{array}{r}12.60 \\
(12.52) \\
\end{array}$ \\
\hline $\begin{array}{l}12 \\
\left(\mathrm{C}_{19} \mathrm{H}_{15} \mathrm{Cl}_{2} \mathrm{~N}_{7} \mathrm{Zn}\right)\end{array}$ & 477.66 & $\begin{array}{l}\text { white } \\
(81.0)\end{array}$ & $>300$ & $\begin{array}{c}47.78 \\
(47.75) \\
\end{array}$ & $\begin{array}{r}3.17 \\
(3.14) \\
\end{array}$ & $\begin{array}{r}20.53 \\
(20.43) \\
\end{array}$ \\
\hline $\begin{array}{l}13 \\
\left(\mathrm{C}_{21} \mathrm{H}_{18} \mathrm{Cl}_{2} \mathrm{~N}_{6} \mathrm{Zn}\right) \\
\end{array}$ & 490.70 & $\begin{array}{l}\text { white } \\
(57.5)\end{array}$ & 271 & $\begin{array}{c}51.40 \\
(51.40) \\
\end{array}$ & $\begin{array}{r}3.70 \\
(3.70) \\
\end{array}$ & $\begin{array}{r}17.13 \\
(17.12) \\
\end{array}$ \\
\hline $\begin{array}{l}14 \\
\left(\mathrm{C}_{22} \mathrm{H}_{18} \mathrm{Cl}_{2} \mathrm{~N}_{4} \mathrm{Zn}\right)\end{array}$ & 474.69 & $\begin{array}{l}\text { white } \\
(43.9) \\
\end{array}$ & $>300$ & $\begin{array}{c}55.67 \\
(55.63) \\
\end{array}$ & $\begin{array}{r}3.82 \\
(3.80) \\
\end{array}$ & $\begin{array}{r}11.80 \\
(11.76) \\
\end{array}$ \\
\hline $\begin{array}{l}15 \\
\left(\mathrm{C}_{11} \mathrm{H}_{16} \mathrm{Cl}_{2} \mathrm{~N}_{4} \mathrm{Cu}\right)\end{array}$ & 338.72 & $\begin{array}{l}\text { yellow } \\
(78.0)\end{array}$ & 206 & $\begin{array}{c}39.01 \\
(39.01)\end{array}$ & $\begin{array}{c}4.76 \\
(4.75)\end{array}$ & $\begin{array}{c}16.54 \\
(16.44)\end{array}$ \\
\hline $\begin{array}{l}\mathbf{1 6} \\
\left(\mathrm{C}_{11} \mathrm{H}_{16} \mathrm{Cl}_{2} \mathrm{~N}_{4} \mathrm{Co}\right)\end{array}$ & 334.11 & $\begin{array}{l}\text { blue } \\
(57.0)\end{array}$ & $>300$ & $\begin{array}{c}39.54 \\
(39.52)\end{array}$ & $\begin{array}{c}4.83 \\
(4.76)\end{array}$ & $\begin{array}{c}16.77 \\
(16.74)\end{array}$ \\
\hline
\end{tabular}

be assigned to $\mathrm{Zn}-\mathrm{N}$ vibration, ${ }^{18,43}$ or $\mathrm{Zn}-\mathrm{Cl}$ vibration if we consider the range described by Socrates. ${ }^{42}$

\section{Thermal analysis}

The stages of decomposition, temperature ranges and decomposition products as well as the weight loss percentages of the complexes are given in Table 3. All the results presented in the Table 3 are proposals of the probable mass losses because the detection was not possible. Figure 1 shows the TGA curve of complexes (12) and (14) as a representative example. All the TGA and derivative thermogravimetric analysis (DTG) are shown in the Supplementary Information section. All the complexes studied here showed degradation by steps with corresponding losses of neutral ligand fragments. In most cases, the complexes were very stable, resulting in a substantial percentage of residual mass after heating to $700{ }^{\circ} \mathrm{C}$. Complex (10) is especially stable, with a percent loss of only $29.0 \%$. By contrast, compound (12) exhibits near-complete decomposition, leaving a residual mass of only $3.1 \%$.
In addition, the probable loss of one of the ligands for compound (8) is observed (3,5-dimethylpirazole) and also two $\mathrm{HCl}$ molecules at $330{ }^{\circ} \mathrm{C}$, corresponding to $52.02 \%$ (calculated $51.45 \%$ ). The losses of $\mathrm{HCl}$ in similar complexes were previously reported by Szécsényi et al. ${ }^{44}$ Finally the decomposition of the other ligand, leaving a residual mass of $11.5 \%$.

An initial loss of $4.47 \%$ is observed in complex (9), which could correspond to the elimination of the methane molecule from the compound, possibly with a methylene bridge connecting the two pyrazoles (calculated mass $4.42 \%$ ). Finally, at approximately $421{ }^{\circ} \mathrm{C}$, a loss of another organic residue is produced $(74.02 \%)$, leaving only the metal (calculated 79.92\%). Compound (10) only presents slight decomposition, losing a fragment that perhaps is related to a methylene group $(4.47 \%), \mathrm{HCl}(13.07 \%)$ and nitrogen $(12.61 \%)$. The values that were calculated for these losses are $4.89,13.38$ and $11.87 \%$, respectively. The TG and DTG curves of the complex (12) and (13) ligand fragment losses are observed, but there was never a complete degradation of the complexes to stabilize the metal with one of the azoles. 
Table 2. Infrared spectral bands for ligands and their complexes

\begin{tabular}{|c|c|c|c|c|c|}
\hline \multirow{2}{*}{$\begin{array}{l}\text { Compound } \\
\mathbf{1}\end{array}$} & \multicolumn{5}{|c|}{ Wavenumber $v / \mathrm{cm}^{-1}$} \\
\hline & $3202 v s$ & $1595 \mathrm{~m}$ & $1306 \mathrm{~s}$ & $1028 s$ & - \\
\hline 8 & 3346vs & $1570 \mathrm{~s}$ & $1272 w$ & $1048 v s$ & $427 w$ \\
\hline 2 & 2980w & $1353 \mathrm{~s}$ & $1267 \mathrm{vs}$ & $1035 \mathrm{~m}$ & - \\
\hline 9 & $3015 w$ & - & $1280 \mathrm{vs}$ & $1051 \mathrm{~m}$ & $494 w$ \\
\hline 3 & $1812 \mathrm{~m}$ & $1507 \mathrm{~s}$ & $1422 s$ & $1275 \mathrm{~s}$ & - \\
\hline 10 & - & $1535 \mathrm{~s}$ & $1465 w$ & $1286 \mathrm{~s}$ & $505 \mathrm{vw}$ \\
\hline 4 & $1605 \mathrm{~m}$ & $1462 \mathrm{~s}$ & $1351 \mathrm{~m}$ & $1214 \mathrm{~m}$ & - \\
\hline 11 & $1607 \mathrm{w}$ & $1469 \mathrm{~m}$ & $1364 \mathrm{~m}$ & $1221 \mathrm{~m}$ & $419 w$ \\
\hline 5 & $1575 \mathrm{~m}$ & $1455 \mathrm{~s}$ & $1225 \mathrm{~s}$ & $1092 \mathrm{~s}$ & - \\
\hline 12 & $1578 \mathrm{~m}$ & $1459 \mathrm{~s}$ & $1230 \mathrm{~s}$ & - & $490 w$ \\
\hline 6 & $1495 \mathrm{~m}$ & 1308w & $1221 \mathrm{~s}$ & $1130 w$ & - \\
\hline 13 & $1496 \mathrm{~m}$ & $1318 \mathrm{~m}$ & $1230 \mathrm{~s}$ & $1142 \mathrm{~m}$ & $488 w$ \\
\hline 7 & $3117 \mathrm{~s}$ & $1511 \mathrm{~s}$ & $1468 \mathrm{~m}$ & $1007 \mathrm{~s}$ & - \\
\hline 14 & $3100 \mathrm{~s}$ & $1520 \mathrm{~s}$ & $1479 w$ & $1035 \mathrm{~m}$ & $559 \mathrm{vw}$ \\
\hline 2 & 2980w & $1353 \mathrm{~s}$ & $1267 \mathrm{vs}$ & $1035 \mathrm{~m}$ & - \\
\hline 15 & $3027 \mathrm{~m}$ & - & 1276vs & $1044 \mathrm{~m}$ & $492 w$ \\
\hline 2 & 2980w & $1353 \mathrm{~s}$ & $1267 \mathrm{vs}$ & $1035 \mathrm{~m}$ & - \\
\hline 16 & $3133 \mathrm{~m}$ & - & $1278 v s$ & $1051 \mathrm{~m}$ & $493 w$ \\
\hline
\end{tabular}

vw: very weak; w: weak; m: medium; s: strong; vs: very strong.

However, compound (12) was the only one that showed a degradation of nearly $100 \%$, and it even lost about $10 \%$ of the total metal mass. In this complex, 3 stages of decomposition were observed. The first was treated from $300-396{ }^{\circ} \mathrm{C}$ and experienced a mass loss of $26.2 \%$, which corresponded probably to the decomposition of the ligand that released a benzotriazole fragment and a methylene bridge (calculated mass, $27.4 \%$ ). Subsequently, it lost $70.7 \%$ of its total mass from $396-700{ }^{\circ} \mathrm{C}$, indicating a multistage decomposition without the generation of a stable intermediary from the remaining fragments (calculated mass, $72.6 \%$ ).

\section{Molecular modeling}

Computational calculations were performed to propose a probable structure for complexes (12) and (13), because these two complexes have different coordination positions with the metal. After seeing the results of the elemental analysis, it is possible to propose a 1:1 stoichiometric relation between the ligand and metal to start the calculation. The results for (12) are presented in Figure 2. These calculations show that complex (12c) is the more favorable structure with the lowest energy of the three possibilities. In this structure, (5) stabilizes the metal as a bidentate ligand in a tetrahedral structure by using the pyridinic nitrogen and the N2 of the benzotriazole moiety. Compounds 12a, 12b and $\mathbf{1 2 c}$ have lower energy compared with the free ligand, $\mathrm{Zn}^{2+}$ and separated chloride anion $(-4296.3699 \mathrm{eV})$. Compound $\mathbf{1 2 c}$ is energetically favored over 12a because the tetrahedral coordination structure is the most stable for this type of complex, and it is also favored over $\mathbf{1 2 b}$ for showing less steric impediment.

Finally, the vibrational frequencies presented in $\mathbf{1 2 c}$ as the minimum potential energy surfaces are positive. In the FTIR spectra, it was possible to find some experimental results that support the proposed structure.

Table 3. Thermoanalytical results (TGA, DTG) for metal complexes

\begin{tabular}{|c|c|c|c|c|c|c|c|}
\hline \multirow{2}{*}{$\begin{array}{l}\text { Compound } \\
\text { (formula) }\end{array}$} & \multirow{2}{*}{ TG range $/{ }^{\circ} \mathrm{C}$} & \multirow{2}{*}{$\mathrm{DTG}_{\max } /{ }^{\circ} \mathrm{C}$} & \multirow{2}{*}{$\mathrm{n}$} & Mass loss & Total mass loss & \multirow{2}{*}{ Assignment } & \multirow{2}{*}{ Metallic residue } \\
\hline & & & & \multicolumn{2}{|c|}{ Estimated (calcd.) /\% } & & \\
\hline 8 & $22-440$ & 330 & 1 & $52.02(51.45)$ & $86.90(85.36)$ & loss of $\mathrm{C}_{5} \mathrm{H}_{8} \mathrm{~N}_{2}$ and $2 \mathrm{HCl}$ & $\mathrm{C}_{2} \mathrm{H}_{2} \mathrm{NZn}$ \\
\hline$\left(\mathrm{C}_{10} \mathrm{H}_{16} \mathrm{Cl}_{2} \mathrm{~N}_{4} \mathrm{Zn}\right)$ & $440-696$ & 503 & 1 & $34.85(33.91)$ & & loss of $\mathrm{C}_{3} \mathrm{H}_{4} \mathrm{~N}$ & \\
\hline 9 & $28-298$ & 308 & 1 & $4.47(4.42)$ & $78.49(84.34)$ & loss of $\mathrm{CH}_{4}$ & $\mathrm{Zn}$ \\
\hline$\left(\mathrm{C}_{11} \mathrm{H}_{16} \mathrm{Cl}_{2} \mathrm{~N}_{4} \mathrm{Zn}\right)$ & $328-700$ & 421 & 1 & $74.02(79.92)$ & & loss of $2 \mathrm{HCl}$ and $\mathrm{C}_{10} \mathrm{H}_{11} \mathrm{~N}_{4}$ & \\
\hline 10 & $26-261$ & 181,238 & 2 & $3.32(4.89)$ & $29.00(30.14)$ & loss of $\mathrm{CH}_{2}$ & $\mathrm{C}_{4} \mathrm{H}_{3} \mathrm{ClN}_{4} \mathrm{Zn}$ \\
\hline$\left(\mathrm{C}_{5} \mathrm{H}_{6} \mathrm{Cl}_{2} \mathrm{~N}_{6} \mathrm{Zn}\right)$ & $261-476$ & 334 & 1 & $13.07(13.38)$ & & loss of $\mathrm{HCl}$ & \\
\hline & $476-694$ & 551,566 & 2 & 12.61(11.87) & & loss of $\mathrm{N}_{2}$ & \\
\hline 11 & $22-375$ & 313 & 1 & $10.20(8.20)$ & $70.72(68.88)$ & loss of $\mathrm{HCl}$ & $\mathrm{C}_{5} \mathrm{H}_{7} \mathrm{~N}_{2} \mathrm{Zn}$ \\
\hline$\left(\mathrm{C}_{19} \mathrm{H}_{24} \mathrm{Cl}_{2} \mathrm{~N}_{4} \mathrm{Zn}\right)$ & $375-700$ & 441 & 1 & $60.52(60.68)$ & & loss of $\mathrm{C}_{14} \mathrm{H}_{18} \mathrm{ClN}_{2}$ & \\
\hline 12 & $30-396$ & 339 & 1 & $26.20(27.67)$ & $96.90(99.70)$ & loss of $\mathrm{C}_{7} \mathrm{H}_{6} \mathrm{~N}_{3}$ & - \\
\hline$\left(\mathrm{C}_{19} \mathrm{H}_{15} \mathrm{Cl}_{2} \mathrm{~N}_{7} \mathrm{Zn}\right)$ & $396-700$ & $471-621$ & 2 & $70.70(72.33)$ & & loss of $\mathrm{C}_{12} \mathrm{H}_{9} \mathrm{Cl}_{2} \mathrm{~N}_{4} \mathrm{Zn}$ & \\
\hline 13 & $22-363$ & 330 & 1 & $20.00(24.07)$ & $51.65(55.79)$ & loss of $\mathrm{C}_{6} \mathrm{H}_{4} \mathrm{~N}_{3}$ & $\mathrm{C}_{6} \mathrm{H}_{14} \mathrm{Cl}_{2} \mathrm{~N}_{3} \mathrm{Zn}$ \\
\hline$\left(\mathrm{C}_{21} \mathrm{H}_{18} \mathrm{Cl}_{2} \mathrm{~N}_{6} \mathrm{Zn}\right)$ & $363-694$ & 516 & 1 & $31.65(31.72)$ & & loss of $\mathrm{C}_{9} \mathrm{H}_{10}$ & \\
\hline 14 & $27-426$ & 319,401 & 2 & $18.41(18.99)$ & $48.12(53.11)$ & loss of $\mathrm{C}_{7} \mathrm{H}_{6}$ & $\mathrm{C}_{7} \mathrm{H}_{5} \mathrm{Cl}_{2} \mathrm{~N}_{2} \mathrm{Zn}$ \\
\hline$\left(\mathrm{C}_{22} \mathrm{H}_{18} \mathrm{Cl}_{2} \mathrm{~N}_{4} \mathrm{Zn}\right)$ & 426-694 & 447,544 & 2 & $29.71(34.11)$ & & loss of $\mathrm{C}_{8} \mathrm{H}_{7} \mathrm{~N}_{2}$ & \\
\hline $\begin{array}{l}\mathbf{1 5} \\
\left(\mathrm{C}_{11} \mathrm{H}_{16} \mathrm{Cl}_{2} \mathrm{~N}_{4} \mathrm{Cu}\right)\end{array}$ & $21-700$ & 384 & 1 & $68.9(70.8)$ & $68.9(70.8)$ & loss of $\mathrm{C}_{11} \mathrm{H}_{16} \mathrm{ClN}_{4}$ & $\mathrm{CuCl}$ \\
\hline 16 & $21-700$ & 429 & 1 & $39.53(39.39)$ & $39.53(39.39)$ & loss of $\mathrm{C}_{5} \mathrm{H}_{8} \mathrm{~N}_{2}$ and $\mathrm{HCl}$ & $\mathrm{C}_{6} \mathrm{H}_{8} \mathrm{ClN}_{2} \mathrm{Co}$ \\
\hline
\end{tabular}

$\left(\mathrm{C}_{11} \mathrm{H}_{16} \mathrm{Cl}_{2} \mathrm{~N}_{4} \mathrm{Co}\right)$

TG: thermogravimetric analysis; DTG: derivative thermogravimetric; n: number of decomposition steps. 

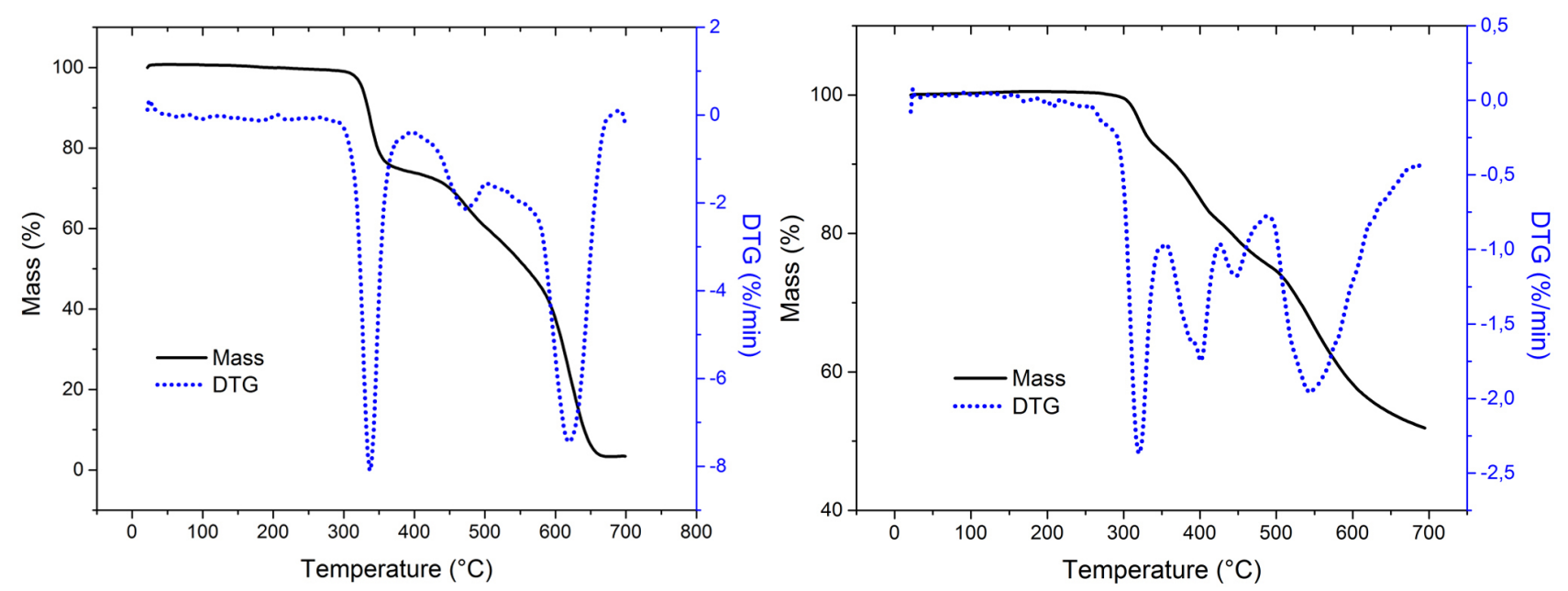

Figure 1. TG and DTG for complexes $\mathbf{1 2}$ (left) and $\mathbf{1 4}$ (right).

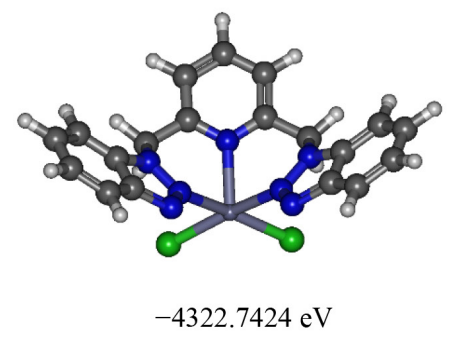

12a

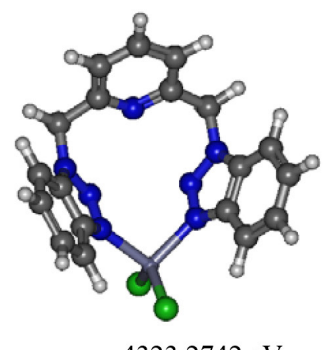

$-4323.2742 \mathrm{eV}$

12b



$-4323.4026 \mathrm{eV}$

$12 \mathrm{c}$

Figure 2. Probable structures for (12) using semi-empirical methods (PM6). Compound 12c was the most probable structure.

A similar analysis was performed in (13) because it is possible to obtain different structures of this complex. Different possibilities were studied, and they are shown in Figure 3. In this case, 13a is more stable than $\mathbf{1 3 b}$ in a vacuum. The total energy of free ligand $\mathbf{6}, \mathrm{Zn}^{2+}$ and $\mathrm{Cl}^{-}$is $-4403.0886 \mathrm{eV}$. The two structures are more stable than the free compounds, and structure 13a is favored because it has fewer steric impediments in comparison with $\mathbf{1 3 b}$. With this information, it was possible to propose 13a as the probable structure of $(\mathbf{1 3})$.
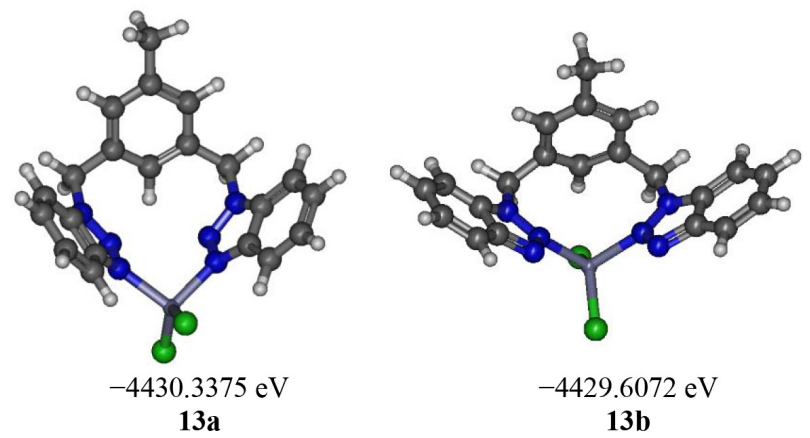

Figure 3. Probable structures for (13) using semi-empirical methods (PM6). Compound 13a was the most probable structure.
Biological activity

The biological activity of the metal salts, ligands and metal complexes were evaluated against all the strains in three replicates. Combinations of ligands and metal salts did not exhibit antimicrobial activity. The in vitro biological screening results are summarized in Table 4. Figure 4 shows the inhibition zones of the complexes $(\mathbf{8}, \mathbf{1 5}$ and $\mathbf{1 6})$ as a representative example.

\section{Antibacterial activity}

The antibacterial activity of the ligand and its complexes were studied against Staphylococcus aureus, methicillin-resistant Staphylococcus aureus (MRSA), Enterococcus faecalis, Bacillus cereus, Escherichia coli, Pseudomonas aeruginosa, Enterobacter aerogenes, Salmonella typhimurium and Shigella flexneri. The metal salts, ligands, metal complexes, standard gentamicin drug and DMSO solvent control were screened separately for their antibacterial activity at concentrations of $100 \mathrm{mM}$, except the standard drug, which was tested at a concentration of $24 \mu \mathrm{gL}^{-1}$ (Figures 5 and 6). These effects were dosedependent. 
Table 4. Antibacterial and antifungal activity (zone of inhibition, diameter in $\mathrm{mm}$ ) of ligands (1-7) and their complexes (8-16) by agar-well diffusion method (concentration used: $100 \mathrm{mM}$ )

\begin{tabular}{|c|c|c|c|c|c|c|c|c|c|c|c|}
\hline \multirow{3}{*}{ Organism } & \multicolumn{11}{|c|}{ Zone of inhibition-diameter / $\mathrm{mm}$} \\
\hline & \multicolumn{11}{|c|}{ Compound } \\
\hline & SD & $1-7$ & 8 & 9 & 10 & 11 & 12 & 13 & 14 & 15 & 16 \\
\hline \multicolumn{12}{|l|}{ Bacteria } \\
\hline S. aureus & $20.4 \pm 0.58$ & - & $15.4 \pm 1.04$ & $9.0 \pm 0.66$ & $13.0 \pm 1.92$ & $12.8 \pm 1.92$ & $15.6 \pm 1.37$ & $16.4 \pm 0.89$ & $14.1 \pm 1.09$ & $16.7 \pm 1.88$ & $17.0 \pm 0.18$ \\
\hline MRSA & $20.8 \pm 0.80$ & - & $14.5 \pm 3.10$ & $11.7 \pm 1.51$ & $14.0 \pm 0.62$ & $14.5 \pm 2.00$ & 20.0 & $17.4 \pm 0.35$ & $13.5 \pm 2.63$ & $16.0 \pm 4.22$ & 14.5 \\
\hline E. faecalis & $20.1 \pm 0.54$ & - & 12.1 & - & - & - & 13.7 & - & - & $22.5 \pm 4.68$ & 18.9 \\
\hline B. cereus & $22.3 \pm 0.35$ & - & $13.1 \pm 0.43$ & 9.4 & $8.9 \pm 0.11$ & $8.6 \pm 0.02$ & 15.5 & $8.5 \pm 0.57$ & $9.2 \pm 0.13$ & $14.8 \pm 0.21$ & 12.02 \\
\hline E. coli & $20.1 \pm 0.11$ & - & $10.9 \pm 0.43$ & - & $8.8 \pm 0.65$ & 9.5 & 7.5 & $11.8 \pm 1.34$ & $10.3 \pm 3.49$ & $10.7 \pm 0.92$ & 17.0 \\
\hline P. aeruginosa & $12.0 \pm 0.59$ & - & $11.0 \pm 0.97$ & - & $9.2 \pm 0.26$ & $8.1 \pm 0.53$ & $10.9 \pm 0.12$ & $9.7 \pm 0.51$ & $8.7 \pm 0.12$ & $13.3 \pm 1.64$ & $12.2 \pm 0.07$ \\
\hline E. aerogenes & $17.2 \pm 0.11$ & - & $9.5 \pm 0.20$ & - & $11.0 \pm 0.07$ & $10.9 \pm 1.09$ & $10.0 \pm 0.12$ & $12.3 \pm 2.56$ & $9.2 \pm 2.51$ & $8.2 \pm 0.20$ & 14.2 \\
\hline S. typhimurium & $16.8 \pm 0.75$ & - & $10.7 \pm 2.09$ & - & $7.9 \pm 1.01$ & $8.9 \pm 0.49$ & 11.6 & $11.5 \pm 2.53$ & $9.8 \pm 2.05$ & $8.2 \pm 2.07$ & 13.2 \\
\hline S. flexneri & $16.6 \pm 0.11$ & - & $14.2 \pm 0.24$ & $9.9 \pm 1.19$ & $13.0 \pm 0.14$ & $11.8 \pm 0.93$ & 13.8 & 13.1 & $11.5 \pm 1.30$ & $9.8 \pm 0.61$ & 28.0 \\
\hline \multicolumn{12}{|l|}{ Fungi } \\
\hline C. albicans & $24.5 \pm 1.78$ & - & - & - & - & - & $9.2 \pm 0.77$ & - & - & $10.5 \pm 1.07$ & $12.7 \pm 3.24$ \\
\hline C. krusei & - & - & - & - & - & - & $7.8 \pm 0.35$ & - & - & $12.0 \pm 2.39$ & $15.7 \pm 2.61$ \\
\hline C. parapsilosis & $31.9 \pm 1.71$ & - & - & - & - & - & $9.7 \pm 0.66$ & - & - & $21.6 \pm 2.26$ & $18.5 \pm 2.28$ \\
\hline A. flavus & - & - & - & - & - & - & - & - & - & - & - \\
\hline A. fumigatus & - & - & - & 28.9 & - & - & - & - & - & 39.7 & - \\
\hline F. oxysporum & - & - & - & - & - & - & - & - & - & - & - \\
\hline F. solani & - & - & - & - & - & - & - & - & - & - & - \\
\hline
\end{tabular}

$\mathrm{SD}=$ standard drug: gentamicin $24 \mu \mathrm{g} \mathrm{mL}{ }^{-1}$ for bacteria, fluconazole $15 \mu \mathrm{g} \mathrm{mL}{ }^{-1}$ for fungi; $100 \mathrm{mM}$ equal in $\mu \mathrm{g} \mathrm{mL} \mathrm{mL}^{-1}$ for each compound: 1: 9613 ; 2: $20428 ; \mathbf{3}: 15015 ; \mathbf{4}: 30843$; 5: 34128; 6: 35442; 7: 33841; 8: 32653; 9: 34056; 10: 28643; 11: 44471; 12: 44766; 13: 49070; 14: 47469; 15: 33872 and 16: 33411.


Figure 4. Inhibition zones of complexes $(8,15$ and 16) against (a) Staphylococcus aureus; (b) Escherichia coli; (c) Candida parapsilosis; and complexes $(\mathbf{9}, \mathbf{1 5}$ and 16) against (d) Aspergillus fumigatus. The positive controls used here consisted of gentamicin $\left(24 \mu \mathrm{g} \mathrm{mL}^{-1}\right)$ for bacteria and fluconazole $(15 \mu \mathrm{g} \mathrm{mL}-1)$ for fungi.

The antibacterial results suggested that all the synthesized metal complexes were effective in at least one of the strains used here, including the four new zinc complexes (11-14). This finding is likely related to the better solubility, bioavailability, and interaction with DNA through intermolecular associations. ${ }^{23,45} \mathrm{Also}$, it is possible that an increase in the lipophilicity of the complexes reduces the permeability barrier of the cells and slows the normal cellular processes of the microorganisms, resulting in increased antimicrobial activity. ${ }^{36}$ The tested gram-positive strain was susceptible to all the metal complexes (Figure 5). However, some of the compounds in this series (9) were not effective against any gram-negative bacteria (Figure 6). Other studies have shown that the pyrazoles in complex (9) inhibit the DNA gyrase and topoisomerase IV in bacteria but are more efficient against gram-positive than gramnegative bacteria. ${ }^{36}$ The presence of different metal ions in the complexes varied with the activity. In compounds ( 9 , 15 and 16), only changes in the metal ion or the presence of copper and cobalt showed inhibitory activity against all bacterial strains. However, complex (9) only inhibited four strains of bacteria, namely those of S. aureus, MRSA, B. cereus, and S. flexneri. Compounds (10) and (13) were inactive against $E$. faecalis but were effective against the remaining bacteria strains, likely because of their abilities to diffuse into the single-cell membrane of the grampositive bacteria, as opposed to the gram-negative bacteria, which have two membranes. The outer membrane of gram-negative bacteria possesses a negative charge, which confers resistance to hydrophobic compounds and therefore makes the membrane more stable, with greater integrity. ${ }^{46}$ 


\section{Comparison of antibacterial activity for gram-positive bacteria (concentration: $100 \mathrm{mM}$ )}

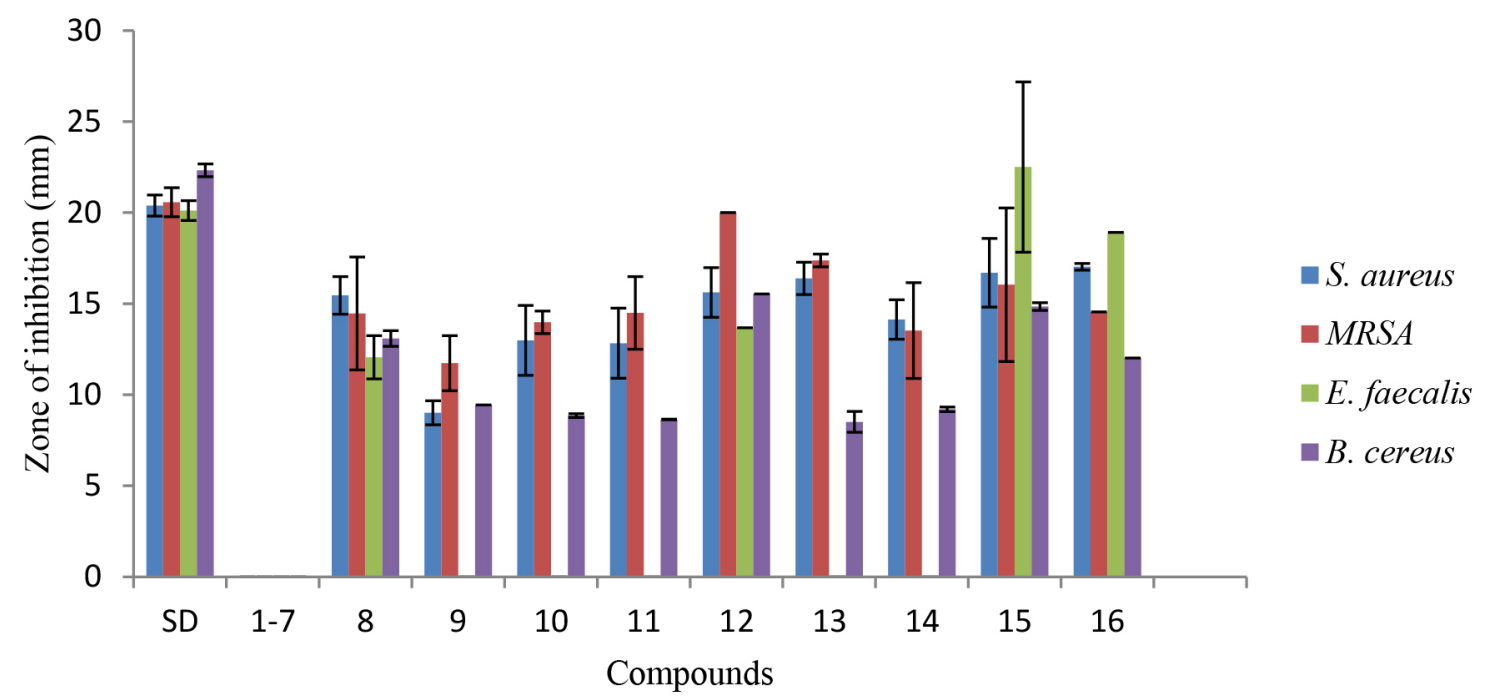

Figure 5. Comparison of antibacterial activity. $\mathrm{SD}=$ standard drug; gentamicin $24 \mu \mathrm{g} \mathrm{mL} \mathrm{L}^{-1}$. The antibacterial screening of all the synthesized compounds was performed against gram-positive Staphylococcus aureus, MRSA, Enterococcus faecalis, and Bacillus. (100 mM equal in $\mu \mathrm{g} \mathrm{mL} \mathrm{m}^{-1}$ for each compound: 1: $9613 ;$ 2: 20428; 3: 15015; 4: 30843; 5: 34128; 6: 35442; 7: 33841; 8: 32653; 9: 34056; 10: 28643; 11: 44471; 12: 44766; 13: 49070; 14: 47469; 15: 33872 and 16: 33411).

\section{Comparison of antibacterial activity for gram-negative (concentration: $100 \mathrm{mM}$ )}



Figure 6. Comparison of antibacterial activities. $\mathrm{SD}=$ standard drug; gentamicin $24 \mu \mathrm{g} \mathrm{mL} \mathrm{L}^{-1}$. The antibacterial screening of all the synthesized compounds was performed against gram-negative Escherichia coli, Pseudomonas aeruginosa, Enterobacter aerogenes, Salmonella typhimurium and Shigella flexneri. The concentration of each compound was similar to that used in Figure 5 and Table 4.

The difference between the new zinc complexes lies in the ligand. In complexes (12) and (13), the benzotriazole in their structures showed increased activity. Benzotriazole derivatives have been shown to be able to induce the alteration of mitochondrial membranes in microorganisms. ${ }^{47}$

As the data analysis further indicated, complex (14) was very similar in its activity to complex (11), indicating that the more extended conjugation of the indazole rings on the metal center does not increase the antibacterial activity. Complexes (9) and (11) differ because of the presence of toluene or methylene in the center (Scheme 3). However, the activity in (11) was effective against eight strains, but for complex (9), it was only effective against four (Figure 5). This finding is most likely explained by the presence of 
toluene in the molecule. Toluene is known to cause an increase in the membrane fluidity and therefore causes an increase in its permeability. ${ }^{48,49}$ In the case of complexes (8) and (9), (8) had activity against all the strains and (9) only showed activity against four. On the basis of these results, we believe that the presence of hydrogen bonding in $\mathbf{8}$ could generates an interaction with proteins that are present in the microorganism cell membranes, resulting in interference with the normal cellular process. ${ }^{50-52}$ These bonds favor interactions with DNA through intermolecular associations as it bridges hydrogen, which in turn results in increased antibacterial activity. ${ }^{12,14}$

\section{Antifungal activity}

The antifungal activities of the ligand and its complexes were studied against C. albicans, C. krusei, C. parapsilosis, A. flavus, A. fumigatus, F. oxysporum, and F. solani. The metal salts, ligands, metal complexes, the standard drug fluconazole, and a DMSO solvent control were screened separately for their antibacterial activities at concentrations of $100 \mathrm{mM}$, except the standard drug, which was tested at $15 \mu \mathrm{g} \mathrm{mL}^{-1}$ (Figure 7). As reported in bacteria, the inhibition effects were dose-dependent.

Fungal species were more resistant to treatments with the new complexes. However, complex (12) showed activity against three fungi strains. This compound contains a benzotriazole group that is uncoordinated from zinc, and it can induce the alteration of mitochondrial membranes in the microorganisms or may inhibit some of the many steps leading to ergosterol synthesis. ${ }^{14}$ Compound (9) only inhibited A. fumigatus. Candida albicans and C. krusei have both shown resistance to azoles, ${ }^{14}$ but they were inhibited by complexes $\left(\mathbf{1 2}, \mathbf{1 5}\right.$ and 16). Mishra et al..$^{53}$ reported that cobalt, copper, and zinc azole complexes showed biological activity against Aspergillus niger and A. flavus, and these complexes disturb the cell respiration process and thus block protein synthesis. This blockage in turn restricts the growth of the organisms. Candida krusei, Fusarium spp., and Aspergillus spp. were not inhibited by the standard drug, that is, fluconazole. However, A. fumigatus and C. krusei were highly inhibited by compound (15).

Fusarium spp. were not inhibited by any complex. Fusarium species are well known to be highly resistant to a variety of antifungals, including azoles, particularly fluconazole,${ }^{54}$ and these strains are also capable of resisting high concentrations of metals such as zinc. ${ }^{55,56}$

The complexes that contained copper and cobalt showed more antifungal activity than the zinc complexes. The tested fungi appear to be zinc-tolerant. Zinc is an essential nutrient for fungi, but it is toxic at high concentrations. Therefore, the intracellular concentration of this metal is tightly regulated by zinc transporters, which could be removing zinc from the fungal cells. ${ }^{57,58}$

In general, complex (15) showed the highest antifungal effects and inhibited the growth of all tested Candida species and also A. fumigatus. Singh et al. ${ }^{16}$ reported

\section{Comparison of antifungal activity (concentration: $100 \mathrm{mM}$ )}

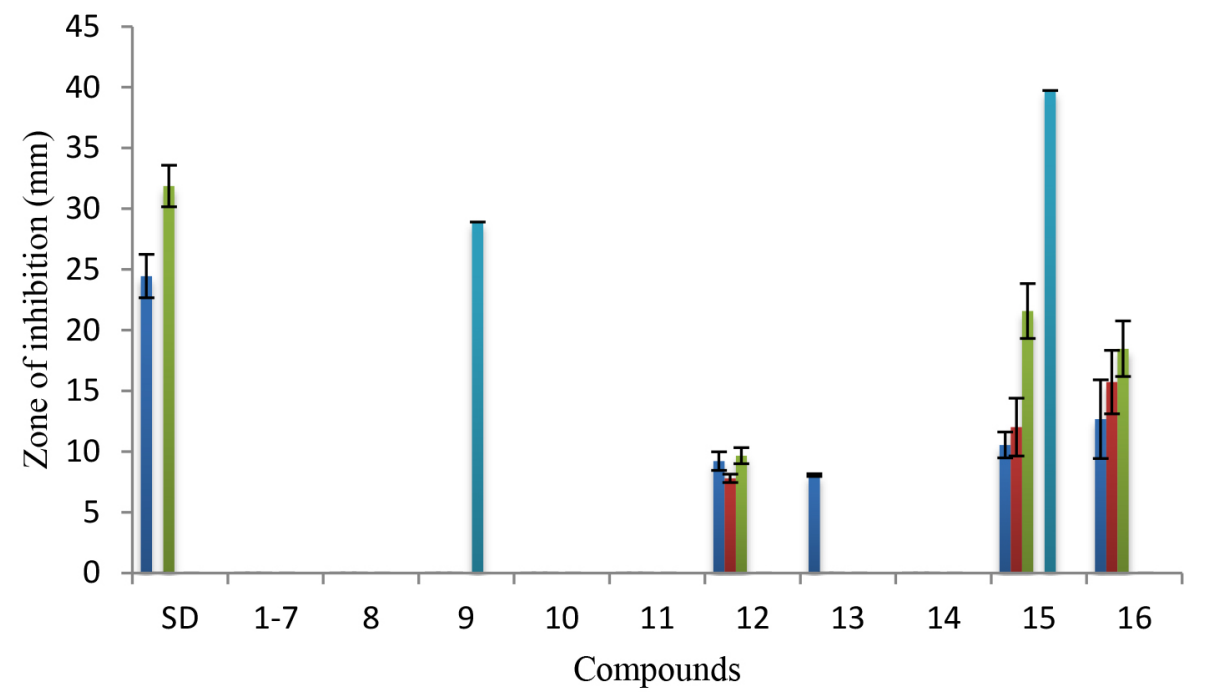

- C. albicans

- C. krusei

- C. parapsilosis

- A. flavus

- A. fumigatus

F. oxysporum

F. solani

Figure 7. Comparison of antifungal activities. SD = standard drug; fluconazole, $15 \mu \mathrm{g} \mathrm{mL} \mathrm{L}^{-1}$. The antifungal screening of all the synthesized compounds was performed against C. albicans, C. krusei, C. parapsilosis, A. flavus and A. fumigatus. The concentration of each compound was similar to that used in Figure 5 and Table 4. 
that the small size of $\mathrm{Cu}^{2+}$ relative to that of other metals such as $\mathrm{Zn}^{2+}$ and $\mathrm{Cu}^{2+}$ reduces polarity and increases the lipophilicity of the fungal membrane, interrupting normal cellular processes and enhancing the antifungal activity of $\mathrm{Cu}^{2+}$ complexes.

\section{Minimum inhibitory concentration $\left(\mathrm{MIC}_{50}\right)$}

The $\mathrm{MIC}_{50}$ values suggest that the antimicrobial activity of complexes (8-16) were species-dependent (Table 2). The results showed low antifungal and antibacterial activities against all the evaluated strains as compared relative to that of the standard drugs gentamicin and fluconazole. The $\mathrm{MIC}_{50}$ values of the complexes ranged from 2454-0.7 $\mu \mathrm{g} \mathrm{mL}^{-1}$ and were slightly higher for gram-negative than gram-positive bacteria. Gram-positive bacteria had an $\mathrm{MIC}_{50}$ of 26 to $2454 \mu \mathrm{g} \mathrm{mL} \mathrm{m}^{-1}$, gram-negative bacteria had an $\mathrm{MIC}_{50}$ of 45 to $2454 \mu \mathrm{g} \mathrm{mL}^{-1}$, and fungi had an $\mathrm{MIC}_{50}$ of 13 to $847 \mu \mathrm{g} \mathrm{mL}^{-1}$. In general, S. aureus and $S$. flexneri were the more susceptible strains.

The highest activity of the complexes against fungi was observed for complex (16) against $C$. krusei, with an $\mathrm{MIC}_{50}$ of $13 \mu \mathrm{g} \mathrm{mL} \mathrm{m}^{-1}$, and for bacteria complex (15) against $S$. aureus, MRSA and E. faecalis, with an $\mathrm{MIC}_{50}$ value of $26 \mu \mathrm{g} \mathrm{mL} \mathrm{mL}^{-1}$. Fungal species were the most resistant, particularly the Fusarium and Aspergillus species. However, our data showed that complexes (15) and (16) possess antifungal activity against $C$. albicans, C. parapsilosis, and the fluconazole-resistant strain of $C$. krusei. Complexes (9) and (15) were efficient at inhibiting the fluconazole-resistant strain of A. fumigatus.

It is clear that pyrazole, imidazole and indazole derivatives combined with metals have strong antibacterial activity against gram-positive and gram-negative bacteria, including MRSA, and also against fluconazole-resistant fungal species such as C. krusei and A. fumigatus. All the tested bacterial species were inhibited by metal complexes (8-16), and Candida albicans and C. krusei, which were both resistant to the azoles, were inhibited by complexes (12, 15 and 16). A. fumigatus was efficiently inhibited by complexes (9 and 15).

\section{Conclusions}

In summary, we have synthesized and characterized a series of air-stable complex derivatives of azole ligands. The ligand 1,3-bis(indazol-1-ylmethyl)benzene (7) and the zinc complexes (11-14) are new. The synthesized azole derivatives (2-7) act as bidentate ligands to coordinate to the metal center. Ligand bonding to metal ions was confirmed by elemental analyses, FTIR spectroscopy studies, TGA and molecular modeling. In vitro assays showed that the

Table 5. $\mathrm{MIC}_{50}\left(\mu \mathrm{g} \mathrm{mL}^{-1}\right)$ of ligands and metal complexes

\begin{tabular}{|c|c|c|c|c|c|c|c|c|c|c|}
\hline \multirow{3}{*}{ Organism } & \multicolumn{10}{|c|}{$\mathrm{MIC}_{50} /\left(\mu \mathrm{g} \mathrm{mL}^{-1}\right)$} \\
\hline & \multicolumn{10}{|c|}{ Compound } \\
\hline & $\mathrm{SD}$ & $1-7$ & 8 & 9 & 10 & 11 & 13 & 14 & 15 & 16 \\
\hline \multicolumn{11}{|l|}{ Bacteria } \\
\hline S. aureus & 0.10 & - & 51 & 107 & 179 & 278 & 154 & 297 & 26 & 209 \\
\hline MRSA & 0.10 & - & 204 & 213 & 358 & 2224 & 2454 & 2373 & 26 & 209 \\
\hline E. faecalis & 3.00 & - & 102 & 426 & 716 & 556 & 1227 & 1187 & 26 & 105 \\
\hline B. cereus & 0.20 & - & 204 & 426 & 358 & 556 & 613 & 1187 & 212 & 418 \\
\hline E. coli & 0.80 & - & 816 & 851 & 716 & 556 & 1227 & 2373 & 1694 & 418 \\
\hline P. aeruginosa & 0.40 & - & 408 & 213 & 716 & 1112 & 2454 & 2373 & 847 & 209 \\
\hline E. aerogenes & 0.10 & - & 816 & 426 & 716 & 2224 & 2454 & 2373 & 847 & 418 \\
\hline S. typhimurium & 1.50 & - & 408 & 213 & 358 & 1112 & 1227 & 2373 & 1694 & 418 \\
\hline S. flexneri & 1.50 & - & 204 & 53 & 45 & 278 & 307 & 297 & 1694 & 52 \\
\hline \multicolumn{11}{|l|}{ Fungi } \\
\hline C. albicans & 0.60 & - & - & - & - & - & - & - & 847 & 52 \\
\hline C. krusei & 15.0 & - & - & - & - & - & - & - & 106 & 13 \\
\hline C. parapsilosis & 4.00 & - & - & - & - & - & - & - & 53 & 52 \\
\hline A. flavus & $>31$ & - & - & - & - & - & - & - & - & - \\
\hline A. fumigatus & $>31$ & - & - & 213 & - & - & - & - & 423 & - \\
\hline F. oxysporum & $>31$ & - & - & - & - & - & - & - & - & - \\
\hline F. solani & $>31$ & - & - & - & - & - & - & - & - & - \\
\hline
\end{tabular}

$\mathrm{SD}=$ standard drug, gentamicin for bacteria, fluconazole for fungi. 
complexes exhibited moderate antibacterial and antifungal activities.

The complex that contains copper was active against all the test strains, except Fusarium spp. and A. flavus. We found that the metal complexes have higher antimicrobial activity, and the ligands themselves have no effect. Metal complexes were more effective at inhibiting bacteria than fungi. These antimicrobial results indicated that structural factors such as the donor groups, sizes and the metallic ions in the complexes could significantly affect their antimicrobial activities. Thus, the agent with a broad-spectrum nature can become a new antimicrobial agent, after further biological studies. Further work in this direction is in progress.

\section{Supplementary Information}

Supplementary information is available free of charge at http://jbcs.sbq.org.br as PDF file.

\section{Acknowledgments}

The authors express their thanks to the Universidad de los Andes for financial support from the Interfaculty project, and J. H. acknowledges the FAPA and Semilla projects at the Faculty of Sciences. Thanks to Vicerrectoría de Investigaciones Universidad de los Andes and Colciencias Beca Francisco Jose de Caldas 547 for providing financial support to the $\mathrm{PhD}$ candidate Fernando Pastrana.

\section{References}

1. Woolhouse, M.; Ward, M.; van Bunnik, B.; Farrar, J.; Philos. Trans. R. Soc., B 2015, 370, 1.

2. Tanwar, J.; Das, S.; Fatima, Z.; Hameed, S.; Interdiscip. Perspect. Infect. Dis. 2014, 2014, 1.

3. Muñoz, P.; Valerio, M.; Vena, A.; Bouza, E.; Posteraro, B.; Lass-Flörl, C.; Sanguinetti, M.; Mycoses 2015, 58, 1.

4. Alcazar-Fuoli, L.; Mellado, E.; Br. J. Haematol. 2014, 166, 471.

5. Sheng, C.; Zhang, W.; Ji, H.; Zhang, M.; Song, Y.; Xu, H.; Zhu, J.; Miao, Z.; Jiang, Q.; Yao, J.; Zhou, Y.; Zhu, J.; Lü, J.; J. Med. Chem. 2006, 49, 2512.

6. Sheng, C.; Zhang, W.; Curr. Med. Chem. 2011, 18, 733.

7. Wang, W.; Wang, S.; Dong, G.; Liu, Y.; Guo, Z.; Miao, Z.; Yao, J.; Zhang, W.; Sheng, C.; MedChemComm 2011, 2, 1066.

8. Zhang, Y.-Y.; Mi, J.-L.; Zhou, C.-H.; Zhou, X.-D.; Eur. J. Med. Chem. 2011, 46, 4391.

9. Pore, V. S.; Jagtap, M. A.; Agalave, S. G.; Pandey, A. K.; Siddiqi, M. I.; Kumar, V.; Shukla, P. K.; MedChemComm 2012, 3, 484.

10. Fang, B.; Zhou, C.-H.; Rao, X.-C.; Eur. J. Med. Chem. 2010, 45,4388 .
11. Wang, X.-L.; Wan, K.; Zhou, C.-H.; Eur. J. Med. Chem. 2010 , $45,4631$.

12. Wang, Y.; Damu, G. L. V.; Lv, J.-S.; Geng, R.-X.; Yang, D.-C.; Zhou, C.-H.; Bioorg. Med. Chem. Lett. 2012, 22, 5363.

13. Sudhir, M. S.; Venkata Nadh, R.; Radhika, S.; Drug Invent. Today 2013, 5, 126.

14. Yu, R.; Ling, Z.; Cheng-He, Z.; Rong-Xia, G.; Med. Chem 2014, 4, 640

15. Banfi, E.; Scialino, G.; Zampieri, D.; Mamolo, M. G.; Vio, L.; Ferrone, M.; Fermeglia, M.; Paneni, M. S.; Pricl, S.; J. Antimicrob. Chemother. 2006, 58, 76.

16. Singh, K.; Kumar, Y.; Puri, P.; Kumar, M.; Sharma, C.; Eur. J. Med. Chem. 2012, 52, 313.

17. Zelenák, V.; Györyová, K.; Mlynarcík, D.; Met.-Based Drugs 2002, 8, 269.

18. Yousef, T. A.; Abu El-Reash, G. M.; Al-Jahdali, M.; El-Rakhawy, E.-B. R.; Spectrochim. Acta, Part A 2014, 129, 163.

19. Pahontu, E.; Fala, V.; Gulea, A.; Poirier, D.; Tapcov, V.; Rosu, T.; Molecules 2013, 18, 8812.

20. Wang, X.; Du, Y.; Liu, H.; Carbohydr. Polym. 2004, 56, 21.

21. Jeeva, J.; Ramachandramoorthy, T.; Res. J. Pharmaceutical Sci. 2013, 2,1 .

22. Thomas, M.; Kulandaisamy, A.; Manohar, A.; Int. J. ChemTech. Res. 2012, 4, 257.

23. An, C.-X.; Han, X.-L.; Wang, P.-B.; Zhang, Z.-H.; Zhang, H.-K.; Fan, Z.-J.; Transition Met. Chem. 2008, 33, 835.

24. Stewart, J. J. P.; MOPAC2012; Stewart Computational Chemistry, Version 15.152W, available at: http://OpenMOPAC. net accessed on April 2016.

25. Maia, J. D. C.; Urquiza Carvalho, G. A.; Mangueira, C. P.; Santana, S. R.; Cabral, L. A. F.; Rocha, G. B.; J. Chem. Theory Comput. 2012, 8, 3072.

26. Allouche, A.-R.; J. Comput. Chem. 2011, 32, 174.

27. Clinical and Laboratory Standards Institute (CLSI); Method for Antifungal Disk Diffusion Susceptibility Testing of Yeasts, NCCLS Document M44-A2; Clinical and Laboratory Standards Institute: Wayne, 2004.

28. Clinical and Laboratory Standards Institute (CLSI); Method for Antifungal Disk Diffusion Susceptibility Testing of Filamentous Fungi, NCCLS Document M51-A; Clinical and Laboratory Standards Institute: Wayne, 2010.

29. Clinical and Laboratory Standards Institute (CLSI); Performance Standards for Antimicrobial Disk Susceptibility Tests, NCCLS Document M02-A11, $11^{\text {th }}$ ed.; Clinical and Laboratory Standards Institute: Wayne, 2012.

30. Clinical and Laboratory Standards Institute (CLSI); Methods for Dilution Antimicrobial Susceptibility Tests for Bacteria that Grow Aerobically, NCCLS Document M07-A9, $9^{\text {th }}$ ed.; Clinical and Laboratory Standards Institute: Wayne, 2012. 
31. Clinical and Laboratory Standards Institute (CLSI); Reference Method for Broth Dilution Antifungal Susceptibility Testing of Yeasts, NCCLS Document M27-A2, $2^{\text {nd }}$ ed.; Clinical and Laboratory Standards Institute: Wayne, 2002.

32. Clinical and Laboratory Standards Institute (CLSI); Reference Method for Broth Dilution Antifungal Susceptibility Testing of Filamentous Fungi, NCCLS Document M38-A; Clinical and Laboratory Standards Institute: Wayne, 2002.

33. Juliá, S.; Sala, P.; del Mazo, J.; Sancho, M.; Ochoa, C.; Elguero, J.; Fayet, J.-P.; Vertut, M.-C.; J. Heterocycl. Chem. 1982, 19, 1141.

34. Hurtado, J.; Carey, D. M.-L.; Muñoz-Castro, A.; ArratiaPérez, R.; Quijada, R.; Wu, G.; Rojas, R.; Valderrama, M.; J. Organomet. Chem. 2009, 694, 2636.

35. Luo, G.; Chen, L.; Dubowchik, G.; J. Org. Chem. 2006, 71, 5392.

36. Singh, N. K.; Singh, S. B.; Singh, D. K.; Chauhan, V. B.; Indian J. Chem. 2003, 42A, 2767.

37. Mesubi, M. A.; Omotowa, B. A.; Transition Met. Chem. 1991, $16,348$.

38. Reedijk, J.; Verbiest, J.; Transition Met. Chem. 1979, 4, 239.

39. Sundaraganesan, N.; Kavitha, E.; Sebastian, S.; Cornard, J. P.; Martel, M.; Spectrochim. Acta, Part A 2009, 74, 788.

40. Lobbia, G. G.; Bonati, F.; Synth. React. Inorg. Met.-Org. Chem. 1988, 18, 551 .

41. Silverstein, R. M.; Kiemle, D.; Webster, F.; Spectrometric Identification of Organic Compounds, $8^{\text {th }}$ ed.; Wiley: Hoboken, 2014.

42. Socrates, G.; Infrared and Raman Characteristic Group Frequencies: Tables and Charts, $3^{\text {rd }}$ ed.; Wiley: Hoboken, 2004.

43. Abd El-Halim, H. F.; Omar, M. M.; Mohamed, G. G.; Spectrochim. Acta, Part A 2011, 78, 36.
44. Szécsényi, K. M.; Leovac, V. M.; Jaćimović, Ž. K.; Češljević, V. I.; Kovács, A.; Pokol, G.; J. Therm. Anal. Calorim. 2001, 66, 573.

45. Patel, P. K.; Patel, P. D.; Int. J. ChemTech Res. 2010, 2, 1147.

46. Denyer, S. P.; Maillard, J.-Y.; J. Appl. Microbiol. 2002, 92, 35S.

47. Zhang, S.-S.; Zhang, H.-Q.; Li, D.; Sun, L.-H.; Ma, C.-P.; Wang, W.; Wan, J.; Qu, B.; Eur. J. Pharmacol. 2008, 584, 144.

48. Sikkema, J.; de Bont, J. A.; Poolman, B.; J. Biol. Chem. 1994, $269,8022$.

49. Heipieper, H. J.; de Bont, J. A.; Appl. Environ. Microbiol. 1994, 60,4440 .

50. Thimmaiah, K. N.; Chandrappa, G. T.; Lloyd, W. D.; Párkányi, C.; Inorg. Chim. Acta 1985, 107, 1.

51. Dharmaraj, N.; Viswanathamurthi, P.; Natarajan, K.; Transition Met. Chem. 2001, 26, 105.

52. Kaim, W.; Schwederski, B.; Klein, A.; Bioinorganic ChemistryInorganic Elements in the Chemistry of Life: an Introduction and Guide, $2^{\text {nd }}$ ed.; Wiley: Hoboken, 2013.

53. Mishra, L.; Singh, V. K.; Indian J. Chem. 1993, 37A, 446.

54. Ghannoum, M. A.; Kuhn, D. M.; Eur. J. Med. Res. 2002, 7, 242.

55. MacDiarmid, C. W.; Milanick, M. A.; Eide, D. J.; J. Biol. Chem. 2003, 278, 15065.

56. Amich, J.; Vicentefranqueira, R.; Leal, F.; Calera, J. A.; Eukaryotic Cell 2010, 9, 424.

57. Baker, M. V.; Bosnich, M. J.; Brown, D. H.; Byrne, L. T.; Hesler, V. J.; Skelton, B. W.; White, A. H.; Williams, C. C.; J. Org. Chem. 2004, 69, 7640.

58. Tu, T.; Assenmacher, W.; Peterlik, H.; Schnakenburg, G.; Dötz, K. H.; Angew. Chem., Int. Ed. 2008, 47, 7127.

Submitted: March 1, 2016

Published online: April 28, 2016 